\title{
Article \\ Flushing of Soils Highly Contaminated with Cd Using Various Washing Agents Derived from Sewage Sludge
}

\author{
Barbara K. Klik, Dorota Kulikowska * and Zygmunt M. Gusiatin (D)
}

check for updates

Citation: Klik, B.K.; Kulikowska, D.; Gusiatin, Z.M. Flushing of Soils Highly Contaminated with Cd Using Various Washing Agents Derived from Sewage Sludge. Energies 2022, 15, 349. https://doi.org/10.3390/ en15010349

Academic Editor: Attilio Converti

Received: 9 November 2021 Accepted: 30 December 2021 Published: 4 January 2022

Publisher's Note: MDPI stays neutral with regard to jurisdictional claims in published maps and institutional affiliations.

Copyright: (C) 2022 by the authors. Licensee MDPI, Basel, Switzerland. This article is an open access article distributed under the terms and conditions of the Creative Commons Attribution (CC BY) license (https:// creativecommons.org/licenses/by/ $4.0 /)$.
Department of Environmental Biotechnology, Faculty of Geoengineering, University of Warmia and Mazury in Olsztyn, 10-719 Olsztyn, Poland; barbara.klik@uwm.edu.pl (B.K.K.); mariusz.gusiatin@uwm.edu.pl (Z.M.G.)

* Correspondence: dorotak@uwm.edu.pl; Tel.: +48-89-523-4145; Fax: +48-89-523-4131

\begin{abstract}
The suitability of sewage-sludge derived washing agents (SS_WAs) (dissolved organic matter DOM; humic-like substances HLS; soluble humic substances SHS), was assessed for removing Cd from highly contaminated $(300 \mathrm{mg} / \mathrm{kg}$ ) sandy clay loam and clay. The soils were remediated via column flushing at two flow rates, 0.5 and $1.0 \mathrm{~mL} / \mathrm{min}$. The stability of the flow velocity (FV) depended on the type of SS_WA and decreased in the following order: DOM $>$ HLS $>$ SHS. Cd was most effectively removed during the first hours of flushing, and the process proceeded with a first-order kinetics. The overall process efficiency was higher at flow rate of $1.0 \mathrm{~mL} / \mathrm{min}$ than at 0.5 $\mathrm{mL} / \mathrm{min}$ and ranged from 65.7 (SHS) to $75.5 \%$ (DOM) for the sandy clay loam and from $64.7 \%$ (SHS) to $67.8 \%$ (DOM) for the clay. However, all SS_WAs at both flow rates removed the most mobile Cd fraction (F1) with an efficiency above $90 \%$. Flushing improved soil characteristics in terms of the content of organic matter, humic substances and nutrients. Among all SS_WAs, DOM was the most suitable for remediation of highly $\mathrm{Cd}$-contaminated soils due to high efficiency of Cd removal, the high stability of its FV during flushing and the simple manner of DOM recovery from sewage sludge.
\end{abstract}

Keywords: soil remediation; column; flow rate; kinetics of Cd removal; soil properties; dehydrogenase

\section{Introduction}

Cadmium $(\mathrm{Cd})$ is one of the most mobile, bioavailable and toxic heavy metals (HMs) in soil. Depending on the anthropogenic source, e.g., nonferrous metal smelting, waste management, agriculture, or urban areas, total $\mathrm{Cd}$ concentrations in soils can range from 6 to $74 \mathrm{mg} / \mathrm{kg}$ [1], or even be extremely high, exceeding values of $300 \mathrm{mg} / \mathrm{kg}$ [2]. Usually, $\mathrm{Cd}$ from anthropogenic sources is highly soluble and very mobile, in contrast to Cd from geogenic materials, which is predominately found in the residual insoluble fraction [3]. Although $\mathrm{Cd}$ is not essential for plant growth or biological systems, it can be uptake by the roots of agricultural crops and transported to the aboveground tissues, including grains [4]. Due to its carcinogenicity, toxicity and common co-occurrence with other soil contaminants, $\mathrm{Cd}$ constitutes a threat to environmental quality, food safety and human health $[5,6]$, and it should be rapidly and permanently removed from soil.

The treatment of soils contaminated with HMs is challenging task for environmental engineers because soil properties and metal concentrations differ greatly, even within small areas $[7,8]$. Soil washing meets the requirements for rapid and efficient metal removal, and it is currently considered a sustainable remediation technique [9]. Soil washing is an ideal method for removing $\mathrm{Cd}$ due to the metal's high mobility [3]. Even though a variety of washing solutions can effectively remove HMs, screening of appropriate washing agents (WAs) should include not only examine their efficiency (improvement of metal mobility and solubility), but also their effect on soil quality. Ideally, a WA should be nontoxic and biodegradable, interact weakly with the soil and allow the soil to retain its fertility [10].

Until now, Cd has typically been removed by soil washing/soil flushing with conventional solutions such as weak inorganic or organic acids [10-12] and synthetic chelators 
(e.g., EDTA) [13]. EDTA has a high capacity for chelating various metals, including Cd, and it can be used to treat a broad range of soil types [14]. $\mathrm{FeCl}_{3}$ alone $[15,16]$ or in combination with other chemicals [17] has effectively removed Cd. Additionally, synthetic anionic surfactants (sodium dodecyl sulfate, sodium laureth sulfate) can be used to treat soils highly contaminated with Cd [18]. However, despite the high efficiency of these conventional washing solutions, they worsen soil properties by reducing $\mathrm{pH}$, damaging texture, removing nutrients and limiting plant growth [16]. This led researchers to search for alternative, eco-friendly and low-cost WAs [19].

There have been attempts to replace recalcitrant EDTA with biodegradable chelators. For example, three biodegradable chelators, N,N-bis (carboxymethyl)-L-glutamate (GLDA), iminodisuccinate (IDS), 3-hydroxy-2,20-iminodisuccinic acid (HIDS), and S,S ethylenediamine-disuccinate (EDDS), were compared with EDTA in terms of their ability to remove Cd [13]. Of these three WAs, only GLDA removed Cd with an efficiency similar to that of EDTA. New organic acid polymers in the form of carboxyalkylthiosuccinic acid and a copolymer of maleic and acrylic acid effectively removed $\mathrm{Cd}$ (52.4 and 49.4\%, respectively) and they had less effect on soil chemical properties than EDTA [20].

Microbial and plant biosurfactants (e.g., rhamnolipids, saponin) can effectively remove $\mathrm{Cd}$ and be more beneficial for overall soil quality than synthetic agents. However, the relatively high cost of biosurfactants or the manner of their production still limits their widespread use [21]. Recently, interest has been directed towards using WAs derived from plant materials and wastes to remove metals, including Cd [22-24]. For example, water extracts from Fagopyrum esculentum, which are rich in carboxyl, hydroxyl, amide, amine and aromatic groups, removed $39.9-40.7 \%$ of $C d$.

Recently, organic wastes can be managed so that they serve as important sources of WAs. Both unprocessed organic wastes (e.g., municipal sewage sludge, agriculture wastes) and organic wastes after processing (e.g., digestated sludge, compost) have been proposed as a source of dissolved organic matter (DOM) for soil remediation [25]. DOM from wastes has the advantages of relatively high reactivity with metals in soil and high contents of nutrients and organic compounds, which can facilitate soil recovery. The use of these solutions can reduce the loss of native nutrients and organic matter from soil during treatment, even if the $\mathrm{pH}$ of the solution is acidic [26]. In our previous studies, it was demonstrated that DOM, soluble humic-like substances (HLS), soluble humic substances (SHS) recovered from municipal sewage sludge have low toxicity, enable high recovery of soil function, and show great potential for remediation of heavily contaminated soils, making them an attractive alternative to $\mathrm{Na}_{2}$ EDTA $[27,28]$. It was found that HLS and SHS are suitable for $\mathrm{Cu}, \mathrm{Pb}$ and $\mathrm{Zn}$ removal via either soil washing or soil flushing, while DOM is suitable only for $\mathrm{Cu}$ and $\mathrm{Zn}$ removal, and not for $\mathrm{Pb}$ removal.

However, even though $\mathrm{Cd}$ is a priority heavy metal, its removal with various forms of soluble organic matter from the same kind of wastes has not been fully investigated, especially in column experiment. Some investigations, however, have indicated that this is a promising approach in batch tests. For example, DOM from wine-processing waste sludge removed $80 \%$ of $\mathrm{Cd}$ [26]. Soil washing with three sewage-sludge washing agents (SS_WAs), DOM, HLS, and SHS, removed $75-82 \%$ of Cd from sandy clay loam and $80-87 \%$ from clay soil, both of which were extremely contaminated with $\mathrm{Cd}(300 \mathrm{mg} / \mathrm{kg})$ [29]. Additionally, the use of these SS_WAs, particularly HLS and SHS, considerably increased the content of the most stable carbon forms, i.e., humic acids, in the soils.

Because $\mathrm{Cd}$ is one of the most mobile metals in soil, it is important to study its removal and behavior in soil under dynamic conditions (soil flushing) and to verify the possibility of restoring highly $\mathrm{Cd}$-contaminated soils under such conditions. These data would be useful for predicting process efficiency when using SS_WAs in field conditions. Therefore, the objective of this study was to evaluate the suitability of three SS_WAs (DOM, HLS and SHS) for removing $\mathrm{Cd}$ from highly contaminated soils with different properties via soil flushing at two SS_WA flow rates $(0.5$ and $1.0 \mathrm{~mL} / \mathrm{min})$. The quality of the post-remediated soils 
was assessed by investigating various soil indicators ( $\mathrm{pH}$, organic matter, humic substances and their fractions, essential macronutrients, $\mathrm{Cd}$ fractions and the activity of soil enzymes).

\section{Materials and Methods}

\subsection{Soils}

In this study, two soils, termed as S1 and S2, were collected from agricultural areas in Baranowo (S1) and Wanguty (S2), both in Warmia and Mazury Province, north-eastern Poland. The soil samples were collected at surface depth $(0-30 \mathrm{~cm})$. In total, about $5 \mathrm{~kg}$ of soil (composite sample) was collected from each location. Detailed characterization of both soils was given in Klik et al. [29]. Briefly, S1 was sandy clay loam in texture; it had a pH of 7.1 , organic matter content of $1.6 \%$ and cation exchange capacity of $12.3 \mathrm{cmol} / \mathrm{kg}$. S2 was clay in texture; it had a $\mathrm{pH}$ of 7.2 , an organic matter content of $2.1 \%$ and a cation exchange capacity of $20.3 \mathrm{cmol} / \mathrm{kg}$. Both native soils were unpolluted with Cd $(0.3 \mathrm{mg} / \mathrm{kg}$ in S1; $0.5 \mathrm{mg} / \mathrm{kg}$ in S2). For simulation of extremely high soil pollution, both soils were spiked with Cd nitrate solution to obtain final Cd concentrations of $300 \mathrm{mg} / \mathrm{kg}$. After spiking, the soils were left at room temperature for 3 months of incubation at $60-65 \%$ of maximum soil water holding capacity, with gentle thorough mixing. Next, the soils were dried at room temperature to a constant mass and used for the soil flushing experiments.

\subsection{Sewage Sludge Washing Agents}

Three SS_WAs used in this study (DOM, HLS, SHS) were extracted from municipal sewage sludge from a mechanical-biological wastewater treatment plant located in Warmia and Mazury Province, Poland. Before extraction, the sewage sludge was dried $\left(105^{\circ} \mathrm{C}\right)$ and ground $(0.5 \mathrm{~mm})$. For DOM extraction, distilled water was used at a proportion of 1:10 (w/v); for extraction of HLS and SHS, $0.1 \mathrm{M} \mathrm{NaOH}$ was used at the same proportion. However, before SHS extraction, the sewage sludge was treated to remove dissolved substances as well as waxes and bitumens according to the methodology provided by Kulikowska and Klimiuk [30]. The concentrations of the SS_WAs were 6.8 (DOM), 9.7 (HLS) and $5 \mathrm{~g} \mathrm{C} / \mathrm{L}$ (SHS). The optimal conditions for metal removal through column flushing, i.e., a concentration of $5 \mathrm{~g} \mathrm{C} / \mathrm{L}$ and a $\mathrm{pH} 4$, were experimentally established in a previous study [29].

\subsection{Cd Removal via Soil Flushing}

The soil flushing experiments were carried out under dynamic conditions in a column reactor for $24 \mathrm{~h}$. The reactor had a length of $30 \mathrm{~cm}$ and an internal diameter of $3 \mathrm{~cm}$. To maintain the proper flow of SS_WAs in the reactor, two layers of washed gravel were used. The total mass of Cd-contaminated soil (50 g) subjected to flushing was selected in previous studies. Two SS_WAs flow rates were used: $0.5 \mathrm{~mL} / \mathrm{min}$ and $1.0 \mathrm{~mL} / \mathrm{min}$. The flow intensity was kept using a peristaltic pump (LeadFluid BT600S, Baoding, China). To simulate soil flushing, top-down flow was used. Every hour, the leachate was collected from an overflow port at the bottom of the reactor by an automatic sampling device. To saturate the soil before it was flushed with SS_WAs, distilled water was passed through the reactor until it filled all pore spaces in the soil (i.e., for $1 \mathrm{~h}$ ). The description and scheme of the column reactor and a detailed description of the laboratory test stand was presented in Klik at al. [28].

In the leachates from the column reactor, the concentrations of $\mathrm{Cd}$ were measured every hour after sample filtration. The physicochemical characteristics of the flushed soil included $\mathrm{pH}$; the total concentration of $\mathrm{Cd}$ and that of its different chemical forms; soil organic matter content, including its content of humic substances (HS), the fulvic fraction (FF) and humic acids (HA); and the content of ammonium nitrogen $\left(\mathrm{N}_{-} \mathrm{NH}_{4}\right)$, available $\mathrm{P}$, and exchangeable $\mathrm{K}, \mathrm{Ca}, \mathrm{Mg}$ and $\mathrm{Na}$. Additionally, as indicators of soil biological activity, soil dehydrogenase activity was determined. 


\subsection{Analytical Methods}

The concentration of the SS_WAs (as total organic carbon) was measured with a Shimadzu Liquid TOC-VCSN analyzer. Soil particle size, i.e., soil texture, was measured with a Mastersizer 2000 particle size analyzer. The $\mathrm{pH}$ was measured potentiometrically $(1: 2.5$ soil to water ratio, $w / v)$. The content of organic matter in soil was measured by the Tiurin method, while the cation exchange capacity (CEC) was measured with the Kappen method [31]. HS, HA and FF were extracted from the soil according to the method described by Boratyński and Wilk [32] (cited in [33]). Measurement of ammonia nitrogen, available $\mathrm{P}$ and exchangeable $\mathrm{K}$ in soils were part of the outsourced analyses executed in accordance with the Polish Standards provided by the National Standards Body in Poland (PB 30ED.303.12.2012, PN-R-04023:1996, PN-R-04022:1996).

The total Cd concentration in both SS_WAs and soil was measured using a flame atomic absorption spectrometer (FAAS) (Varian, AA28OFS, Mulgrave, Australia); therefore, the soil was mineralized with aqua regia in a microwave oven (MarsXpress, CEM, Matthews, NC, USA). The chemical forms of Cd (F1, exchangeable and acid-soluble; F2, reducible; F3, oxidized; and F4, residual) were measured in accordance to the modified Community Bureau of Reference (BCR) methodology described in detail by Pueyo et al. [34] TraceCERT ${ }^{\circledR}$ Cd standard for FAAS (Sigma-Aldrich, Saint Louis, MO, USA) was used to prepare the calibration curve. The accuracy of $\mathrm{Cd}$ analysis by FAAS was validated by analyzing the reference material, CRM $142 \mathrm{R}$. The limit of detection (LOD) for Cd was $0.07 \mathrm{mg} / \mathrm{L}$, while the limit of quantifcation (LOQ) of Cd was $0.21 \mathrm{mg} / \mathrm{L}$.

The activity of soil dehydrogenases (DHA) was determined by the TTC method [35,36]. The method involves soil incubation $\left(37^{\circ} \mathrm{C}, 20 \mathrm{~h}\right.$ in darkness) with a water-soluble substrate, TTC (2,3,5-triphenyltetrazolium chloride), which is enzymatically reduced to waterinsoluble triphenylformazan (TPF). The reaction was carried out in conditions similar to natural ones; therefore, the soil was mixed with $\mathrm{CaCO}_{3}$. DHA in soil is measured as the amount of formazan produced per unit soil mass per unit time ( $\mu \mathrm{mol}$ TPF/g d.m. soil.h, which then was recalculated to $\mu \mathrm{g} \mathrm{TPF} / \mathrm{g}$ d.m. soil·h).

\subsection{Statistical Analysis}

One-way analysis of variance (ANOVA) was performed with Statistica 13.3 software to examine differences in Cd removal with DOM, HLS and SHS from S1 and S2. For comparisons with significant differences identified by ANOVA, further analyses were conducted with Tukey's HSD test.

\section{Results and Discussion}

\subsection{Cd Removal Efficiency and Cd Distribution Patterns}

Cumulative Cd removal during soil flushing depended on soil type, SS_WA type and the flow rate of the SS_WA. In general, Cd was removed more efficiently from S1 than from S2. This was related to the properties of the soils, such as soil texture, organic matter content and sorptive capacity (as CEC) (see Section 2.1), which affected the strength of $\mathrm{Cd}$ bonding in the soil. For all SS_WAs Cd was removed more efficiently at a flow rate of $1.0 \mathrm{~mL} / \mathrm{min}$ than at $0.5 \mathrm{~mL} / \mathrm{min}$ (Figure 1 ).

The difference in Cd removal efficiency between SS_WAs used were noted only at $0.5 \mathrm{~mL} / \mathrm{min}$ : for both soils the process efficiency decreased in this order: DOM $(67.6 \%$ for S1 and $64.3 \%$ for S2) > HLS (65.3\% for S1 and $60.5 \%$ for S2) > SHS $(58.1 \%$ for S1 and $55.3 \%$ for S2). At higher flow rate, in S1 there was no difference in Cd removal efficiency between DOM and HLS (75.5-73.4\%) and the efficiency was lower with SHS (65.7\%). In S2, however, at the higher flow rate, the type of SS_WA did not affect the efficiency of the process.

Although data on the efficiency of $\mathrm{Cd}$ removal in a column reactor are found in the literature, those studies used conventional WAs instead of alternative ones. For example, Juwarkar et al. [37] reported high efficiency of Cd removal (92\%) with $0.1 \%$ di-rhamnolipid biosurfactant. Qiao et al. [11] demonstrated that the application of $0.01 \mathrm{M}$ EDTA at flow rates in the range of $1.0-1.5 \mathrm{~mL} / \mathrm{min}$ removed Cd with $53.2 \%$ efficiency from soil contaminated 
with $\mathrm{Cd}$ and $\mathrm{Pb}$ (initial $\mathrm{Cd}$ concentration of $72.45 \mathrm{mg} / \mathrm{kg}$ ), which, it should be noted, is lower than the efficiency achieved with SS_WAs in the present study.

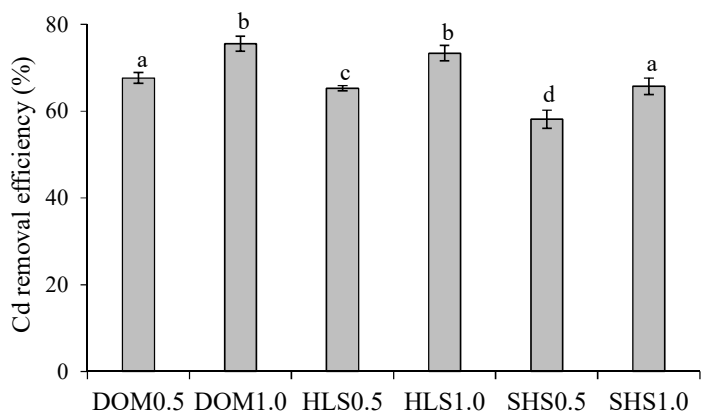

(a)

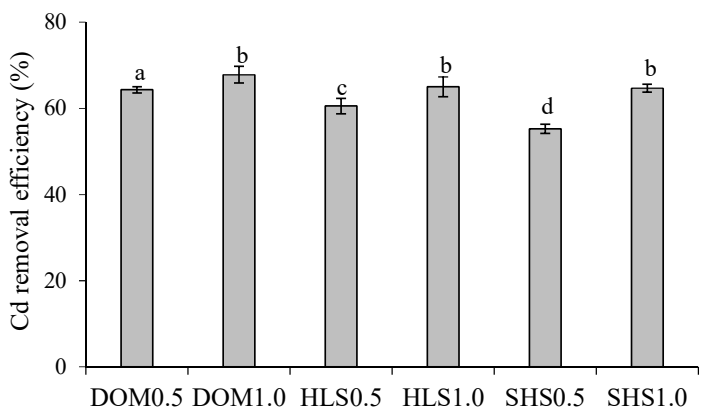

(b)

Figure 1. Cd removal efficiency in the column reactor at two flow rates $(0.5$ and $1.0 \mathrm{~mL} / \mathrm{min})$. The significant differences $(p<0.05)$ between tested variants are marked with small letters: (a) S1 and (b) S2. Small letters mean differences between tested variants in figures.

In our earlier study, the same soils were washed under batch conditions, using the same SS_WAs [29], and Cd was removed with high efficiency: 81.6, 79.4 and 75.3\% from S1, and $86.8,81$ and $79.6 \%$ from S2 with DOM, HLS and SHS, respectively. Under column experiment, Cd was removed with a lower efficiency. Similarly, Mgbeahuruike et al. [38] reported that the efficiency of metal removal from multimetal contaminated soil was higher under batch conditions than under dynamic ones, but the differences in effectiveness depended on the WA used. With citric acid, the efficiency of Cd removal under batch conditions was $55 \%, 11 \%$ higher than under dynamic conditions. With EDDS, however, there was only little difference between batch $(24 \%)$ and dynamic $(23 \%)$ conditions. In contrast, Ugwu et al. [39] reported that removal efficiency with rhamnolipids under dynamic conditions equaled 63.1 and was $9.3 \%$ higher than under batch conditions. However, those authors found that, with EDTA and soapnut from Sapindus mukorossi, the efficiency was slightly higher in batch conditions (ca. 3\%), and with shikakai from Acacia concinna there was little difference between conditions (less than 1\%). Klik et al. [40] compared the efficiency of metal removal $(\mathrm{Cu}, \mathrm{Pb}$ and $\mathrm{Zn})$ between the batch and dynamic conditions. In general, the removal efficiency was higher under batch conditions. For example, DOM removed $\mathrm{Cu}$ with an $92.4 \%$ efficiency under batch conditions, and $65.6 \%$ efficiency at a flow rate of $0.5 \mathrm{~mL} / \mathrm{min}$ and $72.7 \%$ at a flow rate of $1.0 \mathrm{~mL} / \mathrm{min}$ under dynamic conditions. Despite the fact that the flow rate in the reactor was increased twice, the removal efficiency was still lower than in batch conditions (by almost 20\%). The authors point out that this phenomenon is due to the way soil contacts with WAs, which is more vigorous under batch conditions. Additionally, the higher ratio of soil mass to volume of the washing solution is responsible for the high efficiency in batch compared to dynamic washing.

In this study, despite some differences in soil properties, such as soil texture and soil organic matter content, the pattern of Cd distribution was similar in both soils (S1, sandy clay loam and S2, clay) (Figure 2). The share of the individual fractions of $\mathrm{Cd}$ in the unflushed soils decreased in this order: F2 $>$ F1 $>$ F3 $>$ F4, which corresponded to $\mathrm{Cd}$ concentrations of $223.1,75.6,4.38$ and $0.71 \mathrm{mg} / \mathrm{kg}$ in S1, and 231.6, 68.0, 12.8 and $1.3 \mathrm{mg} / \mathrm{kg}$ in S2. 

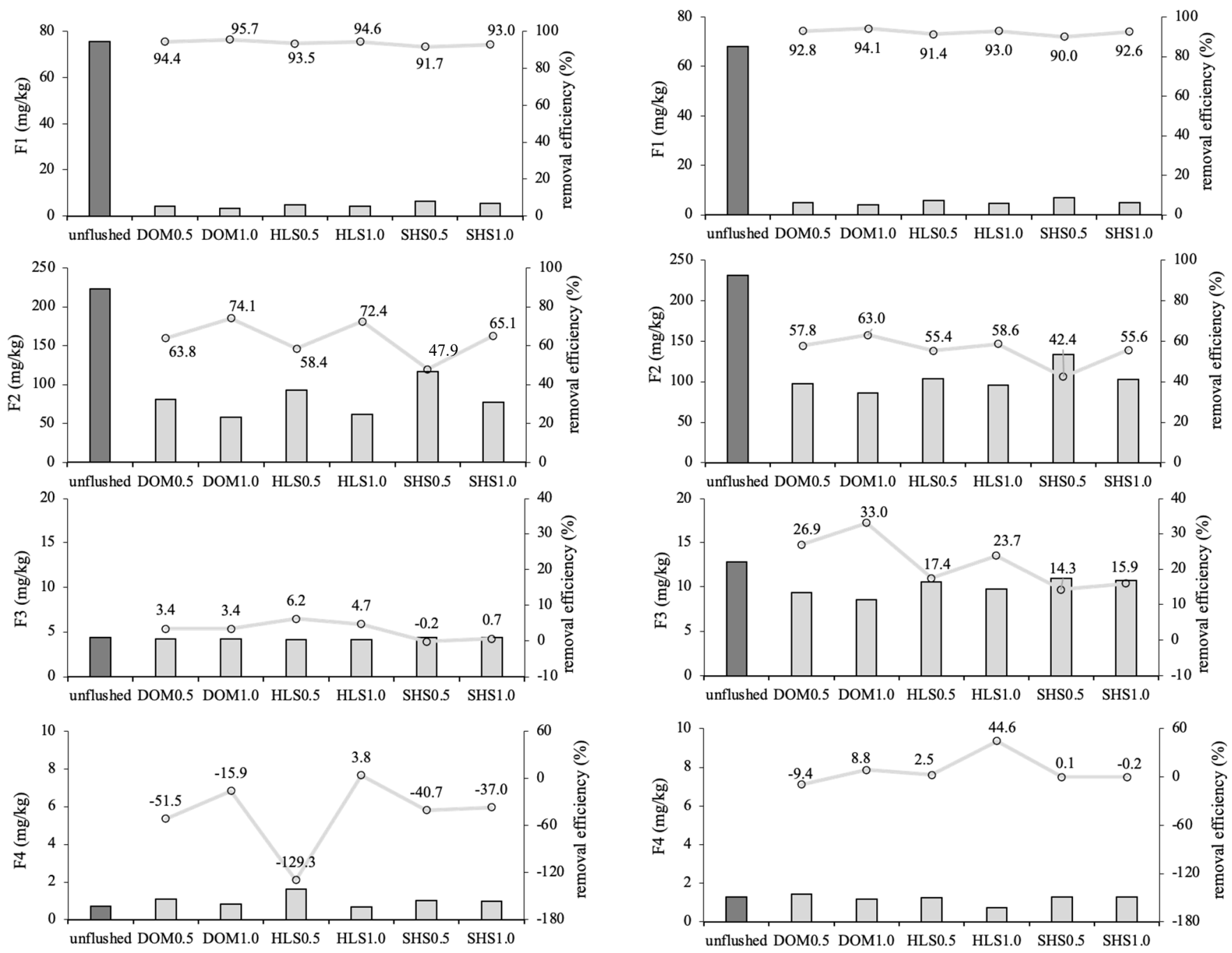

(a)

(b)

Figure 2. Distribution of chemical forms (F1, exchangeable and acid-soluble; F2, reducible; F3, oxidized and F4, residual) and the efficiency of their removal with DOM, HLS, and SHS in (a) S1, (b) S2.

Regardless of the soil type, the overall efficiency of Cd removal was determined mainly by metal removal from the two fractions with the largest shares of total $\mathrm{Cd}$ content. i.e., the mobile F1 fraction and the potentially mobile F2 fraction. As Cd is one of the most mobile metals, it was removed from the F1 fraction with the highest efficiency (91.7-95.7\% removal from S1 and 90-94.1\% from S2) (Figure 2). These results indicate that the need to change flow rate during soil flushing might be important when the metal is present mostly in fractions other than the mobile F1 fraction.

Indeed, with regard to the F2 fraction, the effects of the flow rate and the type of SS_WA were important for Cd removal. With S1, for example, Cd removal from the F2 fraction equaled to $63.8 \%$ (DOM), $58.4 \%$ (HLS) and $47.9 \%$ (SHS) at a flow rate $0.5 \mathrm{~mL} / \mathrm{min}$, and it increased 1.17, 1.24 and 1.36-fold when the flow rate was increased to $1 \mathrm{~mL} / \mathrm{min}$. Thus, the flow rate has a greater effect on $\mathrm{Cd}$ removal from the F2 fraction when using SHS than when using the other two SS_WAs. Although Cd removal from the F2 fraction of S2 was lower than its removal from this fraction in S1, equaling to 57.8\% (DOM), 55.4\% (HLS) and $42.4 \%$ (SHS) at a flow rate of $0.5 \mathrm{~mL} / \mathrm{min}$, increasing the flow rate also increased the efficiency of $\mathrm{Cd}$ removal from this soil (from 1.1-fold with DOM to 1.3-fold with SHS). 
Qiao et al. [11] obtained similar results in column experiment with EDTA. They found that $\mathrm{Cd}$ was removed mainly from the exchangeable (70.48\% removal) and Fe-Mn oxide fractions (81.90\% removal). The overall efficiency of $\mathrm{Cd}$ removal was lower in their study than in the present authors' study because they had a relatively high share of $\mathrm{Cd}$ in the organic fraction $(16.47 \%)$, whereas in the present study, only $1.5 \%$ (S1) and $4 \%$ (S2) of the $\mathrm{Cd}$ was in this fraction.

As was mentioned, soil flushing in the study presented here removed little Cd from the F3 and F4 fractions, due in part to the low shares of this metal in these fractions. Gusiatin et al. [41] obtained similar results in column reactor with tannic acid. Those authors indicated that soil washing changed the distribution of metals, including $\mathrm{Cd}$, regardless of the applied flow rate, which is consistent with the observations of the present study. According to Nejad et al. [42], Cd in the residual fraction cannot be released into the environment within a limited time and may be less easily extracted, even by chemically enhanced washing. After remediation, $\mathrm{Cd}$ is associated mainly with nonlabile soil fractions (as chemically stable mineral forms). As a result, it is less mobile in the soil environment than it was in the primary conditions before remediation [43]. Thus, greater metal removal from the F1 and F2 fractions than from the F3 and F4 fractions during soil washing/flushing can be beneficial for increasing the stability of residual metals after remediation.

\subsection{Stability of Flow Velocity during Soil Flushing}

The maintenance of proper hydraulic conditions in a column reactor is crucial for effective soil flushing. The monitoring of flow velocity (FV) during soil flushing is very often omitted in column experiments assuming that it is the same during the whole process of soil treatment. Changes in the FV during soil flushing can be an important factor affecting metal removal. In this study, the values of the FV of the different SS_WAs in the column reactor were plotted to show the relationship between FV and flushing time, for two flow rates $(0.5$ and $1.0 \mathrm{~mL} / \mathrm{min})$ and two soil types (S1 and S2). For a given curve of $\mathrm{FV}$, the slope of the best-fit line corresponds to the decrease in FV (in $\mathrm{mL} / \mathrm{h}$ ) during $1 \mathrm{~h}$ of flushing time. For all SS_WAs, the relationship between flushing time and FV is shown in Figure 3.

As planned, the total time of soil flushing was $24 \mathrm{~h}$. With S1 (Figure 3a) and a flow rate of $0.5 \mathrm{~mL} / \mathrm{min}(30 \mathrm{~mL} / \mathrm{h})$, stable FV was maintained for $11 \mathrm{~h}$ with DOM, and for shorter periods of time with HLS and SHS, 10 and $8 \mathrm{~h}$, respectively (gray areas on Figure 3). After that, the hydraulic conditions in the column became unstable and the FV began to decrease. It should be emphasized that, regardless of the SS_WA that was used, the decrease in FV was in the range of $0.82-0.84 \mathrm{~mL} / \mathrm{h}$, i.e., if the flushing time was extended beyond 11,10 or $8 \mathrm{~h}$ (for DOM, HLS and SHS, respectively), the FV decreased by about $0.82-0.84 \mathrm{~mL} / \mathrm{h}$. At the higher flow rate of $1 \mathrm{~mL} / \mathrm{min}(60 \mathrm{~mL} / \mathrm{h})$, the time during which a stable FV was maintained was decreased to $6 \mathrm{~h}$ for DOM and HLS, and $4 \mathrm{~h}$ for SHS (Figure 3b). Moreover, the subsequent decreases in FV were ca. two-times higher $(1.72-1.86 \mathrm{~mL} / \mathrm{h})$. Thus, at a flow rate of $60 \mathrm{~mL} / \mathrm{h}$, stable hydraulic conditions were maintained for a relatively short period of time, after which the FV decreased by about $1.72-1.86 \mathrm{~mL} / \mathrm{h}$.

With S2, the changes in FV were similar, although it remained stable for shorter periods of time. At a flow rate of $0.5 \mathrm{~mL} / \mathrm{min}(30 \mathrm{~mL} / \mathrm{h})$, the $\mathrm{FV}$ remained stable for 10,8 and $6 \mathrm{~h}$ with DOM, HLS and SHS, respectively (Figure 3c). With SHS, the time that the FV remained stable was 1.3-fold shorter in S2 than in S1, which was the largest such difference of the tested WAs. At a flow rate of $1 \mathrm{~mL} / \mathrm{min}(60 \mathrm{~mL} / \mathrm{h})$ in $\mathrm{S} 2$, the FV remained stable for the shortest periods of time: $4 \mathrm{~h}$ with DOM and HLS, and only $3 \mathrm{~h}$ with SHS (Figure $3 \mathrm{~d}$ ). Note that, as was observed with a flow rate of $0.5 \mathrm{~mL} / \mathrm{min}$, the difference in the time of stable FV between the two soils was largest with SHS. Moreover, the FV of SHS decreased by the largest amount when the flow rate was increased in S2. 
(a)

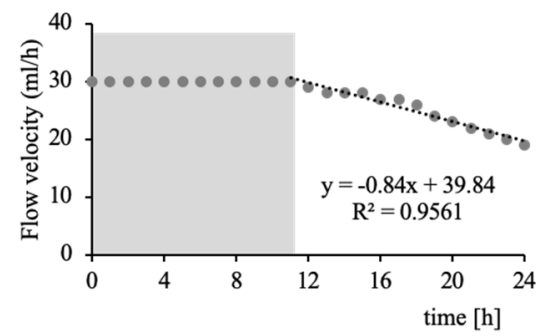

(b)

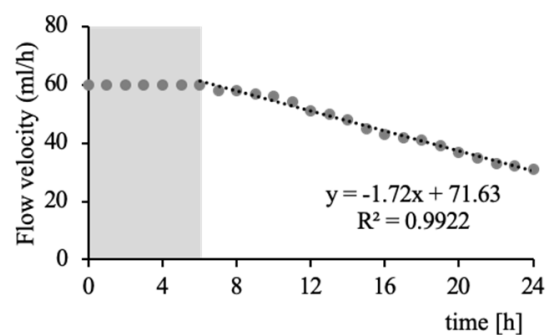

(c)

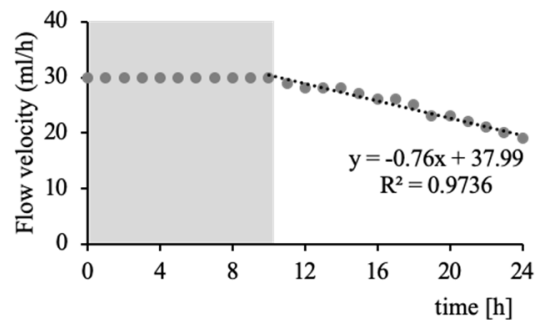

(d)

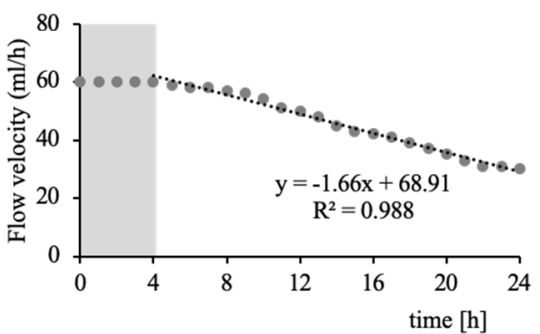

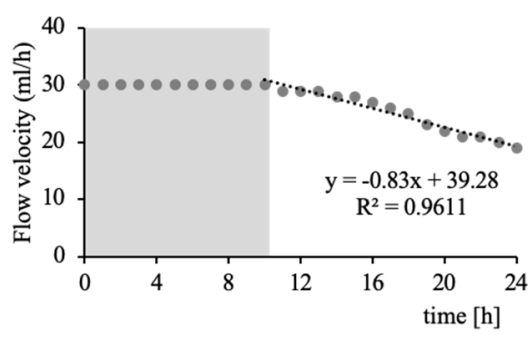
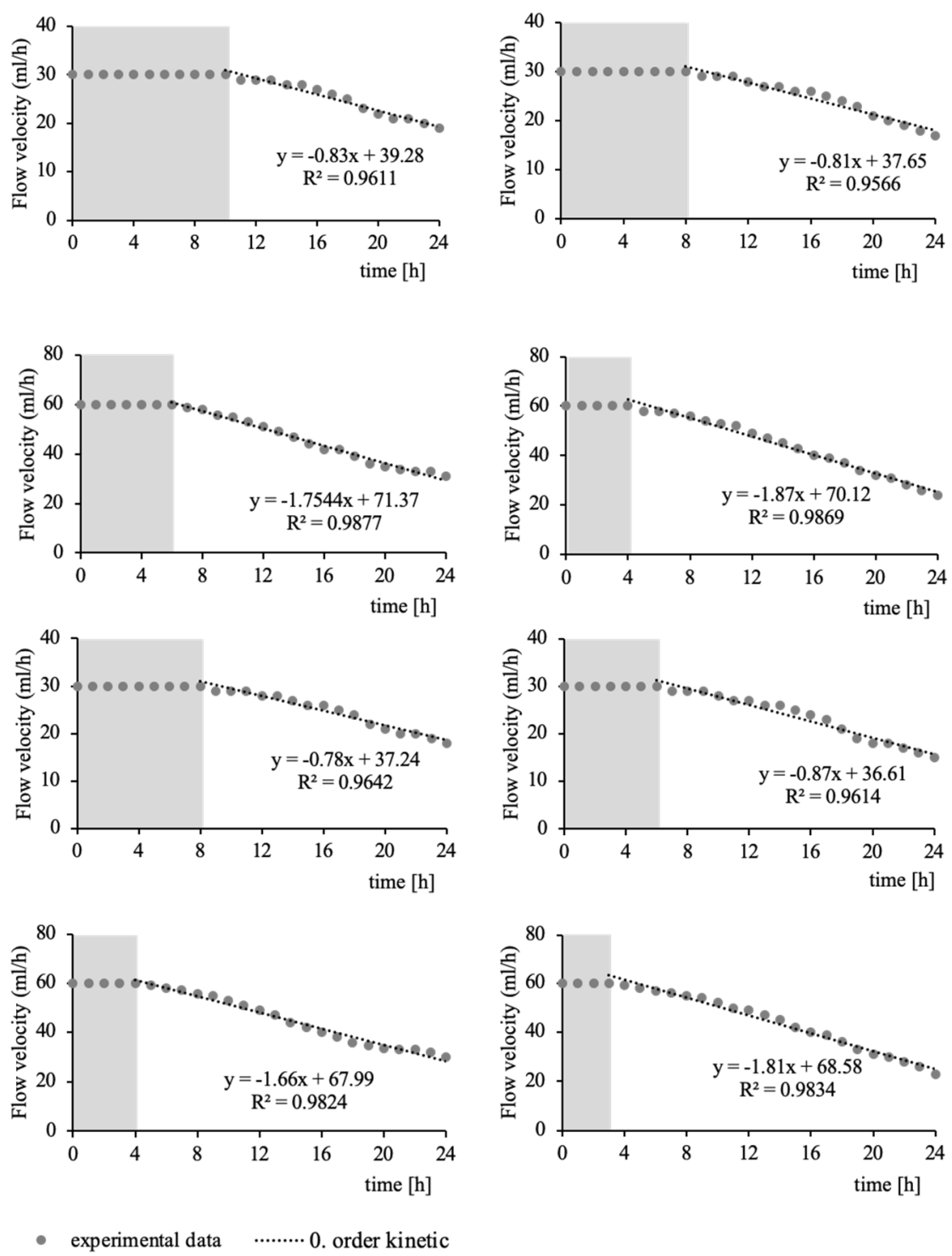

Figure 3. Flow velocity in the column experiment for S1: at (a) $0.5 \mathrm{~mL} / \mathrm{min}$ and (b) $1.0 \mathrm{~mL} / \mathrm{min}$ and for S2: at (c) $0.5 \mathrm{~mL} / \mathrm{min}$ and (d) $1.0 \mathrm{~mL} / \mathrm{min}$ (left—DOM; middle—HLS; right—SHS).

Changes in hydraulic conditions are rather typical during soil flushing; they can be due to certain characteristics of the WA and soil. So far it was stated that the greater decrease in flow velocity is noted with higher chelating-agent concentrations. Higher concentrations of WAs can cause plugging due to dispersion of fine soil fractions or formation of viscous emulsions $[44,45]$. In our study, all SS_WAs were used at the same concentration. Therefore, the differences in FV stability could have been caused by differences in the soluble organics present in the waste-derived washing agents. Whereas DOM contained mainly low-molecular-weight organic acids and fulvic acids, SHS contained mainly highmolecular-weight organics such as fulvic and humic acids [27]. The mass transfer of SHS differed from that of DOM, due to the composition of SHS and its higher sorption in soil, which was reflected by the differences in the stability of the FV during column flushing.

The stability of the FV is also related to the soil texture. Our earlier study [28] used the same column and the same SS_WAs, but lighter soil (sandy loam). A stable FV was maintained for approximately eight pore volumes, which corresponded to flushing times of $16 \mathrm{~h}$ at $0.5 \mathrm{~mL} / \mathrm{min}(30 \mathrm{~mL} / \mathrm{h})$ and $8 \mathrm{~h}$ at $1.0 \mathrm{~mL} / \mathrm{min}(60 \mathrm{~mL} / \mathrm{h})$. In the sandy clay loam in the present study, a stable FV was maintained for $8-11 \mathrm{~h}(30 \mathrm{~mL} / \mathrm{h})$ or $4-6 \mathrm{~h}(60 \mathrm{~mL} / \mathrm{h})$. In the clay, the time with a stable FV was even shorter $(6-10 \mathrm{~h}$ at $30 \mathrm{~mL} / \mathrm{h}$ and $3-4 \mathrm{~h}$ at 
$60 \mathrm{~mL} / \mathrm{h}$ ). Thus, the present results and those of our previous study [28] indicate that the time of stable FV varies with soil type in the following order (from longest to shortest): sandy loam > sandy clay loam > clay.

\subsection{Kinetics of $\mathrm{Cd}$ Removal}

At both flow rates, all the tested SS_WAs removed a large amount of $\mathrm{Cd}$ from both soils during the first hour of flushing. After $10 \mathrm{~h}$ of flushing $\mathrm{S} 1$ at a flow rate of $0.5 \mathrm{~mL} / \mathrm{min}$, $84.4 \%$ (DOM) to $90 \%$ (SHS) of Cd had been removed; while at flow rate of $1 \mathrm{~mL} / \mathrm{min}$, $88-89 \%$ of Cd had been removed. After $10 \mathrm{~h}$ of flushing S2 at $0.5 \mathrm{~mL} / \mathrm{min}, 84.4 \%$ (DOM) to $88.3 \%$ (HLS) of the Cd had been removed; at the higher flow rate, $89.8 \%$ (HLS) to $92.6 \%$ (DOM) had been removed. Qiao et al. [11] also observed that the largest amount of Cd was removed during the first hours of column flushing.

Based on cumulative $\mathrm{Cd}$ removal, kinetic constants were calculated, according the 1 . order kinetic formula:

$$
C=C_{\max } \cdot\left(1-\mathrm{e}^{-k \cdot t}\right),
$$

where $C_{\max }$ is the maximum concentration of $C d$ removed from the washed soil $(\mathrm{mg} / \mathrm{kg})$; $k$ is the kinetic constant of $\mathrm{Cd}$ removal $\left(\mathrm{h}^{-1}\right) ; t$ is the soil flushing time (h). Based on the values of $C_{\max }$ and $k$, the initial rate of Cd removal, $r(\mathrm{mg} / \mathrm{kg} \cdot \mathrm{h})$, was calculated.

With $\mathrm{S} 1$, the values of $k$ only differed slightly between flow rates (Figure 4, Table 1). However, it should be emphasized that the flow rate influenced the maximum concentration of $C d$ removed from $S 1\left(C_{\max }\right)$. With all SS_WAs, $C_{\max }$ was $12-13 \%$ higher at a flow rate of $1 \mathrm{~mL} / \mathrm{min}$ than at $0.5 \mathrm{~mL} / \mathrm{min}$. Consequently, in all cases, the initial rate of Cd removal, $r$, was higher at the higher flow rate. With $\mathrm{S} 2$, the value of $k$ differed between flow rates to the greatest extent when DOM was used, and $r$ was $34.6 \mathrm{mg} / \mathrm{kg} \cdot \mathrm{h}$ at $0.5 \mathrm{~mL} / \mathrm{min}$ and increased $34 \%$ (to $46.5 \mathrm{mg} / \mathrm{kg}$.h) at $1 \mathrm{~mL} / \mathrm{min}$.

(a)

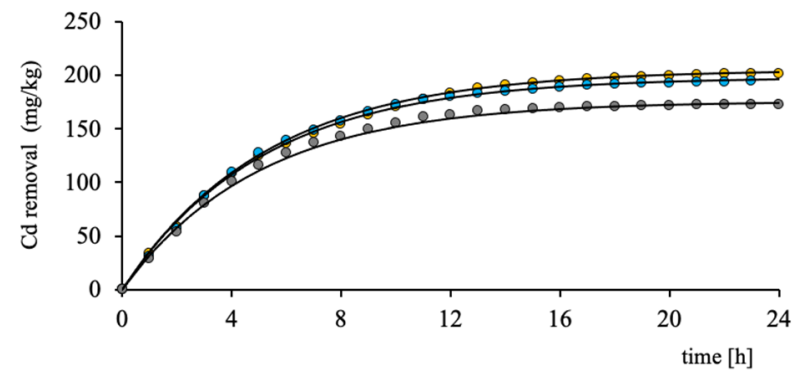

(b)

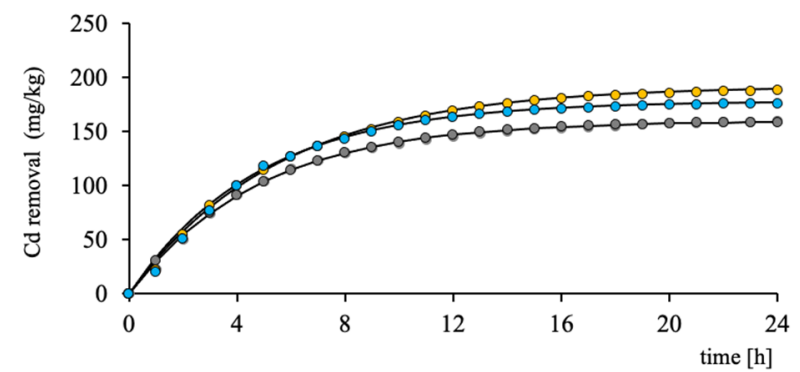

(c)

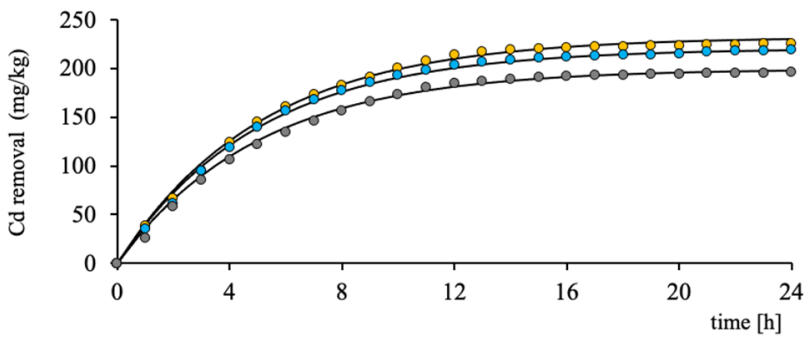

(d)

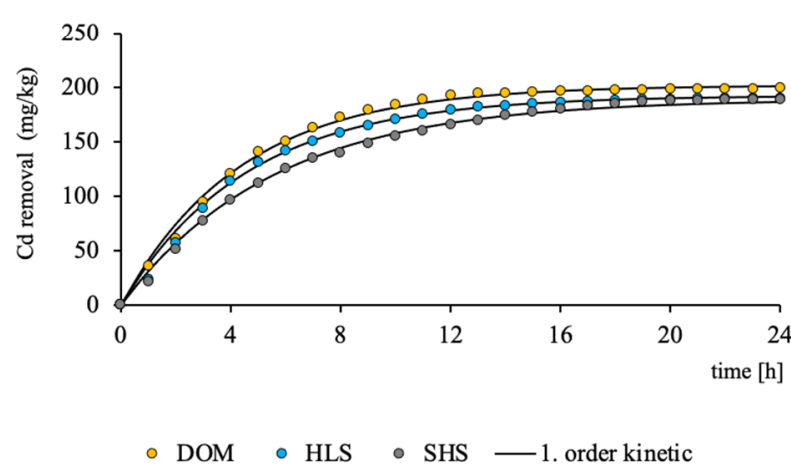

Figure 4. Cumulative Cd removal at $0.5 \mathrm{~mL} / \mathrm{min}$ for (a) $\mathrm{S} 1$, (b) $\mathrm{S} 2$ and at $1.0 \mathrm{~mL} / \mathrm{min}$ for (c) S1, (d) S2. 
Table 1. Kinetic parameters of cumulative Cd removal.

\begin{tabular}{|c|c|c|c|c|c|c|c|}
\hline \multirow{2}{*}{ Parameter } & \multirow{2}{*}{ Flow Rate } & \multicolumn{3}{|c|}{$\mathrm{S} 1$} & \multicolumn{3}{|c|}{$\mathrm{S} 2$} \\
\hline & & DOM & HLS & SHS & DOM & HLS & SHS \\
\hline \multirow{2}{*}{$k\left[\mathrm{~h}^{-1}\right]$} & $0.5 \mathrm{~mL} / \mathrm{min}$ & 0.19 & 0.19 & 0.21 & 0.18 & 0.21 & 0.21 \\
\hline & $1.0 \mathrm{~mL} / \mathrm{min}$ & 0.19 & 0.2 & 0.2 & 0.23 & 0.22 & 0.18 \\
\hline \multirow{2}{*}{$\begin{array}{c}C_{\max } \\
{[\mathrm{mg} / \mathrm{kg}]}\end{array}$} & $0.5 \mathrm{~mL} / \mathrm{min}$ & 205 & 198 & 176 & 192 & 178 & 160 \\
\hline & $1.0 \mathrm{~mL} / \mathrm{min}$ & 232 & 221 & 199 & 202 & 192 & 189 \\
\hline \multirow{2}{*}{$r[\mathrm{mg} / \mathrm{kg} \cdot \mathrm{h}]$} & $0.5 \mathrm{~mL} / \mathrm{min}$ & 39.0 & 37.6 & 37.0 & 34.6 & 37.4 & 33.6 \\
\hline & $1.0 \mathrm{~mL} / \mathrm{min}$ & 44.1 & 44.2 & 39.8 & 46.5 & 42.2 & 34.0 \\
\hline
\end{tabular}

With all the SS_WAs tested in our previous study, for $\mathrm{Cu}, \mathrm{Pb}$ and $\mathrm{Zn}$ removal in column experiments with different soils, the flow rate did not influence $k$ values, but it did influence the maximum concentration of HMs removed from the soil [28]. Thus, the observations of our previous study and those of our study presented here are similar, except for Cd removal from S2 with DOM.

\subsection{Valorization of Flushed Soil}

In this study, the valorization of flushed soil was assessed based on its $\mathrm{pH}$, its content of nutrients and organic matter (including organic matter fractions), and the enzymatic activity in the soil. In all flushed soils, the $\mathrm{pH}$ decreased (Table 2), which resulted from the use of SS_WAs with a slightly acidic $\mathrm{pH}$. The remediation process substantially influenced the content of organic matter, including HS content, and this effect was most visible during soil flushing with SHS.

Soil flushing also influenced other soil characteristics. In general, S1 had a higher content of ammonium nitrogen, available $\mathrm{P}$, exchangeable $\mathrm{Mg}$, $\mathrm{Ca}$ and $\mathrm{Na}$ than soil $\mathrm{S} 2$, but a lower content of exchangeable $\mathrm{K}$. More nutrients were transferred to the soil at the higher flow rate (i.e., $1.0 \mathrm{~mL} / \mathrm{min}$ ) than at the lower one. Soil washing with HLS increased the content of ammonium nitrogen and available $\mathrm{P}$ in soil to the greatest extent, suggesting that the content of these nutrients in the washing solution was high. The content of $\mathrm{Na}$ in the soils washed with HLS and SHS was relatively high, resulting from that the fact that these flushing agents were prepared with $\mathrm{NaOH}$. In contrast, flushing changed the content of exchangeable $\mathrm{Ca}$ to a minimal extent. In contaminated S1 and S2, exchangeable Ca content was 176.8 and $129.6 \mathrm{mg} / \mathrm{kg}$, and it had changed after flushing by only $2.3-15.1 \mathrm{mg} / \mathrm{kg}$, regardless of the SS_WA and flow rate.

Soil enzyme activity can reflect soil quality and may therefore be a useful indicator of soil contamination (e.g., with HMs) and the recovery of soil function after remediation. As it is known that dehydrogenase activity (DHA) participates in the biochemical pathways of soil biogeochemical cycles and assures their correct sequence, as well as being sensitive to HMs present in soil, DHA was used to assess the quality of the soil and the degree of regeneration of degraded soils in this study.

Regardless of the soil type, the flushing process had a significant effect on the DHA activity (Figure 5). In the unflushed soils, the DHA activity was extremely low: $3.6 \mu \mathrm{g}$ $\mathrm{TPF} / \mathrm{g}$ d.w.'h in S1 and $2.9 \mu \mathrm{g} \mathrm{TPF} / \mathrm{g}$ d.w.h in S2. The flushing process increased DHA 4.3- to 7.5-fold in S1 and 5.5- to 9.2-fold in S2. In S1, washing with HLS and SHS increased DHA more than washing with DOM (Figure 5a), and the difference in DHA after flushing with HLS and SHS was not statistically significant. In this soil, the DHA was higher after applying HLS and SHS at higher flow rate. In S2, DHA was highest after flushing with SHS (26.7 $\mu \mathrm{g} \mathrm{TPF} /(\mathrm{g}$ d.w. h); low rate of $1.0 \mathrm{~mL} / \mathrm{min})$. In this soil, a higher DHA was observed only when SHS was used at higher flow rate (Figure $5 b$ ). 
Table 2. Physicochemical characteristics of the soils ( $n=3, \pm$ standard deviation).

\begin{tabular}{|c|c|c|c|c|c|c|c|c|c|c|c|c|c|}
\hline Soil & SS_Was ${ }^{(1)}$ & $\begin{array}{c}\text { Flow } \\
\text { Rate } \\
\mathrm{mL} / \mathrm{min}\end{array}$ & $\begin{array}{c}\mathrm{pH} \\
-\end{array}$ & $\begin{array}{c}\text { Organic } \\
\text { Matter } \\
\%\end{array}$ & $\begin{array}{l}\text { Humic } \\
\text { Substances } \\
\mathrm{mg} / \mathrm{kg}\end{array}$ & $\begin{array}{l}\text { Fulvic } \\
\text { Fraction } \\
\mathrm{mg} / \mathrm{kg}\end{array}$ & $\begin{array}{l}\text { Humic Acid } \\
\mathrm{mg} / \mathrm{kg}\end{array}$ & $\begin{array}{l}\mathrm{NH}_{4}{ }^{(2)} \\
\mathrm{mg} / \mathrm{kg}\end{array}$ & $\begin{array}{c}\mathrm{P}_{2} \mathrm{O}_{5}{ }^{(3)} \\
\mathrm{mg} / \mathrm{kg}\end{array}$ & $\begin{array}{l}\mathrm{K}_{2} \mathrm{O}^{(3)} \\
\mathrm{mg} / \mathrm{kg}\end{array}$ & $\begin{array}{l}\mathrm{Mg}^{(3)} \\
\mathrm{mg} / \mathrm{kg}\end{array}$ & $\begin{array}{l}\mathrm{Ca}^{(3)} \\
\mathrm{mg} / \mathrm{kg}\end{array}$ & $\begin{array}{l}\mathrm{Na}^{(3)} \\
\mathrm{mg} / \mathrm{kg}\end{array}$ \\
\hline \multirow{5}{*}{ S1 } & \multicolumn{2}{|c|}{ Unflushed } & $7.1 \pm 0.1$ & $1.6 \pm 0.08$ & $4.8 \pm 0.25$ & $2.0 \pm 0.3$ & $2.8 \pm 0.54$ & $19.7 \pm 1.1$ & $176.6 \pm 11.9$ & $125.4 \pm 9.9$ & $72.2 \pm 7.4$ & $176.8 \pm 18.4$ & $44.9 \pm 3.5$ \\
\hline & DOM & $\begin{array}{l}0.5 \\
1.0\end{array}$ & $\begin{array}{l}6.3 \pm 0.1 \\
6.1 \pm 0.1\end{array}$ & $\begin{array}{c}1.87 \pm 0.06 \\
1.94 \pm 0.1\end{array}$ & $\begin{array}{l}7.04 \pm 0.58 \\
7.26 \pm 0.42\end{array}$ & $\begin{array}{l}2.90 \pm 0.4 \\
3.21 \pm 0.5\end{array}$ & $\begin{array}{c}4.14 \pm 0.9 \\
4.05 \pm 0.17\end{array}$ & $\begin{array}{l}57.8 \pm 3.7 \\
64.8 \pm 4.6\end{array}$ & $\begin{array}{l}316.54 \pm 17.1 \\
367.45 \pm 22.3\end{array}$ & $\begin{array}{l}374.22 \pm 20.5 \\
384.53 \pm 26.9\end{array}$ & $\begin{array}{c}92.47 \pm 7.4 \\
106.36 \pm 6.1\end{array}$ & $\begin{array}{l}168.25 \pm 14.2 \\
180.29 \pm 10.3\end{array}$ & $\begin{array}{c}141.26 \pm 9.3 \\
176.48 \pm 12.2\end{array}$ \\
\hline & \multirow{2}{*}{ HLS } & 0.5 & $6.2 \pm 0.1$ & $2.01 \pm 0.09$ & $7.48 \pm 0.44$ & $3.02 \pm 0.5$ & $4.46 \pm 0.6$ & $60.8 \pm 5.6$ & $332.58 \pm 19.1$ & $348.71 \pm 20.1$ & $76.18 \pm 5.8$ & $175.25 \pm 8.4$ & $196.47 \pm 11.9$ \\
\hline & & 1.0 & $6.1 \pm 0.2$ & $2.17 \pm 0.07$ & $7.99 \pm 0.54$ & $3.31 \pm 0.3$ & $4.68+ ++ \pm 0.88$ & $62.5 \pm 6.0$ & $393.15 \pm 24.2$ & $417.82 \pm 28.3$ & $88.53 \pm 4.5$ & $176.54 \pm 8.7$ & $229.10 \pm 9.6$ \\
\hline & SHS & 0.5 & $6.2 \pm 0.1$ & $3.27 \pm 0.1$ & $11.49 \pm 0.77$ & $4.38 \pm 0.2$ & $7.11 \pm 0.65$ & $27.4 \pm 2.1$ & $319.84 \pm 24.7$ & $351.07 \pm 28.5$ & $81.46 \pm 6.1$ & $170.39 \pm 13.8$ & $258.17 \pm 10.4$ \\
\hline \multirow{7}{*}{ S2 } & \multicolumn{2}{|c|}{ Unflushed } & $7.2 \pm 0.2$ & $2.1 \pm 0.11$ & $6.8 \pm 0.2$ & $4.3 \pm 0.4$ & $2.6 \pm 0.2$ & $14.2 \pm 2.8$ & $157.9 \pm 17.1$ & $213.6 \pm 18.7$ & $64.3 \pm 5.7$ & $129.6 \pm 10.6$ & $30.4 \pm 6.7$ \\
\hline & \multirow{2}{*}{$\mathrm{DOM}$} & 0.5 & $6.4 \pm 0.1$ & $2.43 \pm 0.09$ & $7.92 \pm 0.6$ & $5.13 \pm 0.4$ & $2.79 \pm 0.3$ & $52.8 \pm 3.1$ & $288.55 \pm 20.5$ & $436.85 \pm 22.5$ & $69.82 \pm 6.9$ & $116.74 \pm 10.8$ & $102.85 \pm 8.4$ \\
\hline & & 1.0 & $6.3 \pm 0.1$ & $2.48 \pm 0.13$ & $8.19 \pm 0.63$ & $5.11 \pm 0.5$ & $3.08 \pm 0.3$ & $58.5 \pm 3.4$ & $306.16 \pm 25.9$ & $454.69 \pm 27.9$ & $70.14 \pm 7.3$ & $124.59 \pm 9.3$ & $114.26 \pm 14.1$ \\
\hline & \multirow{2}{*}{ HLS } & 0.5 & $6.5 \pm 0.2$ & $2.88 \pm 0.08$ & $9.51 \pm 0.72$ & $5.83 \pm 0.4$ & $3.68 \pm 0.2$ & $49.9 \pm 3.8$ & $312.86 \pm 30.1$ & $419.63 \pm 21.3$ & $73.58 \pm 6.7$ & $123.63 \pm 11.6$ & $131.47 \pm 11.8$ \\
\hline & & 1.0 & $6.3 \pm 0.1$ & $3.11 \pm 0.12$ & $10.16 \pm 0.79$ & $6.46 \pm 0.7$ & $3.7 \pm 0.3$ & $54.9 \pm 4.1$ & $337.43 \pm 26.6$ & $447.42 \pm 20.4$ & $74.96 \pm 8.3$ & $136.47 \pm 13.9$ & $149.63 \pm 16.6$ \\
\hline & \multirow{2}{*}{ SHS } & 0.5 & $6.5 \pm 0.1$ & $4.5 \pm 0.14$ & $14.28 \pm 0.9$ & $9.23 \pm 0.6$ & $5.05 \pm 0.4$ & $29.6 \pm 3.1$ & $268.8 \pm 24.5$ & $411.62 \pm 35.6$ & $70.86 \pm 6.4$ & $108.54 \pm 9.3$ & $197.58 \pm 10.4$ \\
\hline & & 1.0 & $6.4 \pm 0.2$ & $4.93 \pm 0.11$ & $16.22 \pm 0.86$ & $10.35 \pm 0.8$ & $5.87 \pm 0.3$ & $33.2 \pm 2.9$ & $299.42 \pm 28.4$ & $436.92 \pm 31.4$ & $74.18 \pm 6.1$ & $122.48 \pm 10.5$ & $218.49 \pm 11.9$ \\
\hline
\end{tabular}

${ }^{(1)}$ Washing agents; ${ }^{(2)}$ ammonium nitrogen; ${ }^{(3)}$ available and exchangeable forms of $\mathrm{P}, \mathrm{K}, \mathrm{Mg}$, Ca and $\mathrm{Na}$. 


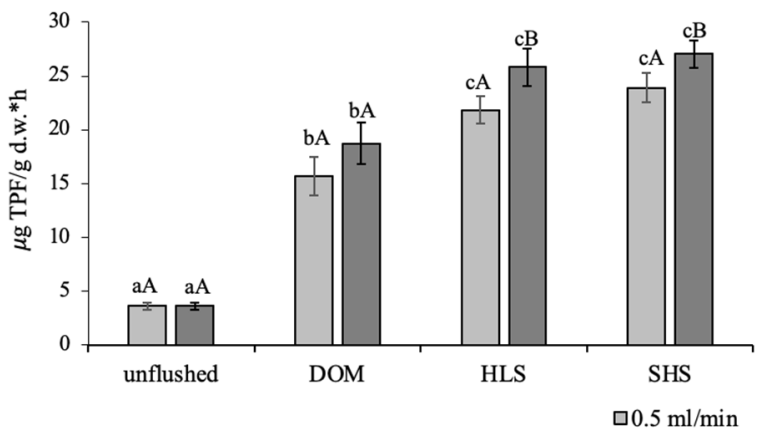

(a)

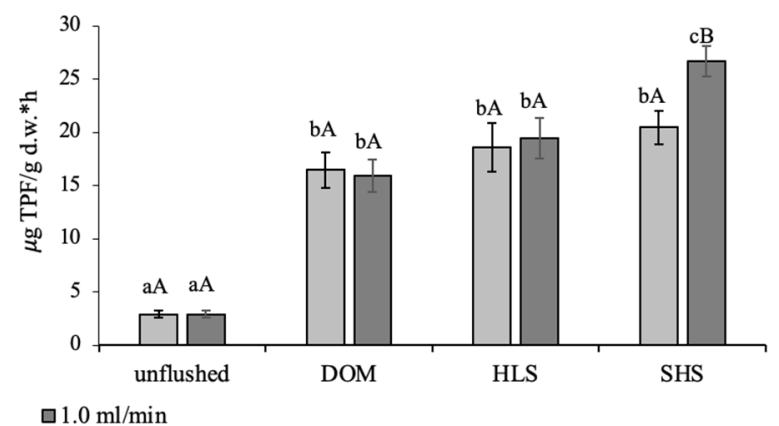

(b)

Figure 5. Dehydrogenase activity (DHA) before and after soil flushing: (a) S1, (b) S2. Significant differences $(p<0.05)$ between tested washing agents are marked with small letters, while between different flow rates are marked with large letters.

It is known that high concentrations of $\mathrm{Cd}$ in the soil disrupt the activity of enzymes (including DHA). In general, HMs at high concentrations in soil can cause cell apoptosis, damage in cell metabolic pathways, or denaturation of enzymatic proteins, which is associated with a reduction in microbial biomass, and thus a reduction in enzyme activity [46-48]. In our study, although the overall Cd removal efficiency ranged from $65.7 \%$ for SHS to $75.5 \%$ for DOM (S1) and from $64.7 \%$ for SHS to $67.8 \%$ for DOM (S2) (both at $1.0 \mathrm{~mL} / \mathrm{min}$ ), $\mathrm{Cd}$ removal from the most mobile fractions (F1) was very high, exceeding $90 \%$. This high removal from the F1 fraction would explain the increase in DHA after flushing, as $\mathrm{Cd}$ in this fraction inhibits soil enzyme activity.

Additionally, the increase in DHA after flushing may also be due to the enrichment of soil organic matter after flushing, which was most noticeable after flushing with SHS. Higher soil organic-matter content provides more substrate to support increased microbial mass, which is reflected by higher enzyme production [49]. Thus, the high DHA in the soils after HLS and SHS flushing may be also connected with the increase in total organic matter content in general, and the increase in HS content in particular, because HS stabilizes enzymes by forming complexes with them [50]. It should also be remembered that the effect of Cd on DHA depends on soil characteristics [51]. For example, in clay-loam and clay soils, higher DHA and lower Cd bioavailability results from its complexation with organic substances [52,53]. In general, $\mathrm{Cd}$ is more toxic in sandy soils than in clay soils, because clay is the abiotic component of soils causes the greatest reduction in Cd toxicity $[47,54,55]$.

\section{Conclusions}

Column soil flushing with the SS_WAs effectively removed Cd from highly contaminated $(300 \mathrm{mg} / \mathrm{kg})$ soils with sandy clay loam and clay textures. At a flow rate of $1.0 \mathrm{~mL} / \mathrm{min}$, DOM and HLS had comparable Cd removal efficiency (75.5-73.4\%) from sandy clay loam, and it was lower with SHS (65.7\%). In clay however, at the higher flow rate, the type of SS_WA did not affect the process efficiency. The difference in Cd removal efficiency between tested SS_WAs was noted only at $0.5 \mathrm{~mL} / \mathrm{min}$ : for both soils the process efficiency decreased in this order: DOM (67.6\% for S1 and 64.3\% for S2) > HLS $(65.3 \%$ for $\mathrm{S} 1$ and $60.5 \%$ for S2) > SHS (58.1\% for S1 and 55.3\% for S2). This means that type of SS_WAs influenced Cd removal efficiency mainly in sandy clay loam and in clay only at lower flow rate. All SS_WAs effectively decreased Cd mobility in both soils (over $90 \%$ removal of the F1 fraction). HLS and SHS increased soil DHA activity and organic matter content (including humic substances and their fractions) to a larger extent than DOM. However, taking into account process efficiency, stability of flow velocity during column treatment, and the inexpensiveness and eco-friendliness of extraction from sewage sludge (water vs. alkaline solvent), DOM is recommended for effective Cd removal from highly contaminated soil via column flushing. 
Author Contributions: B.K.K.: contributed to conceptualized and designed the study, carried out the experiment, writing the paper; Z.M.G. and D.K.: conceptualized and designed the study, contributed to the interpretation of the results and writing the paper. All authors have read and agreed to the published version of the manuscript.

Funding: This research was funded by the Ministry of Education and Science in Poland (subsidy for research 29.610.024-110). Publication (Open Access) of this research was financially supported by Minister of Education and Science in the range of the program entitled "Regional Initiative of Excellence" for the years 2019-2022, project No. 010/RID/2018/19, amount funding 12,000,000 PLN.

Institutional Review Board Statement: Not applicable.

Informed Consent Statement: Not applicable.

Data Availability Statement: Not applicable.

Acknowledgments: The authors gratefully thank Mark Leonard, a native speaker of English, for English language support.

Conflicts of Interest: The authors declare no conflict of interest. The funders had no role in the design of the study; in the collection, analyses, or interpretation of data; in the writing of the manuscript, or in the decision to publish the results.

\section{References}

1. Bi, X.; Feng, X.; Yang, Y.; Qiu, G.; Li, G.; Li, F.; Liu, T.; Fu, Z.; Jin, Z. Environmental contamination of heavy metals from zinc smelting areas in Hezhang County, western Guizhou, China. Environ. Int. 2006, 32, 883-890. [CrossRef]

2. Ettler, V. Soil contamination near non-ferrous metal smelters: A review. Appl. Geochemistry 2016, 64, 56-74. [CrossRef]

3. Liu, Y.; Xiao, T.; Perkins, R.B.; Zhu, J.; Zhu, Z.; Xiong, Y.; Ning, Z. Geogenic cadmium pollution and potential health risks, with emphasis on black shale. J. Geochem. Explor. 2017, 176, 42-49. [CrossRef]

4. Hu, Y.; Cheng, H.; Tao, S. The challenges and solutions for cadmium-contaminated rice in China: A critical review. Environ. Int 2016, 92, 515-532. [CrossRef] [PubMed]

5. Bi, D.; Yuan, G.; Wei, J.; Xiao, L.; Feng, L.; Meng, F.; Wang, J. A soluble humic substance for the simultaneous removal of cadmium and arsenic from contaminated soils. Int. J. Environ. Res. Public Health 2019, 16, 4999. [CrossRef]

6. Haider, F.U.; Liqun, C.; Coulter, J.A.; Cheema, S.A.; Wu, J.; Zhang, R.; Wenjun, M.; Farooq, M. Cadmium toxicity in plants: Impacts and remediation strategies. Ecotoxicol. Environ. Saf. 2021, 211, 111887. [CrossRef]

7. Radomirović, M.; Ćirović, Ž.; Maksin, D.; Bakić, T.; Lukić, J.; Stanković, S.; Onjia, A. Ecological risk assessment of heavy metals in the soil at a former painting industry facility. Front. Environ. Sci. 2020, 8, 560415. [CrossRef]

8. Kupka, D.; Kania, M.; Pietrzykowski, M.; Łukasik, A.; Gruba, P. Multiple factors influence the accumulation of heavy metals (Cu, $\mathrm{Pb}, \mathrm{Ni}, \mathrm{Zn}$ ) in forest soils in the Vicinity of Roadways. Water Air Soil Pollut. 2021, 232, 194. [CrossRef]

9. Soil Washing Application. United States Environmental Protection Agency. Available online: https://clu-in.org/techfocus/ default.focus/sec/soil_washing/cat/Application/ (accessed on 8 November 2021).

10. Wang, Z.; Wang, H.; Wang, H.; Li, Q.; Li, Y. Effect of soil washing on heavy metal removal and soil quality: A two-sided coin. Ecotoxicol. Environ. Saf. 2020, 203, 11098. [CrossRef]

11. Qiao, J.; Sun, H.; Luo, X.; Zhang, W.; Mathews, S.; Yin, X. EDTA-assisted leaching of Pb and Cd from contaminated soil. Chemosphere 2017, 167, 422-428. [CrossRef]

12. Beiyuan, J.; Lau, A.Y.; Tsang, D.C.; Zhang, W.; Kao, C.M.; Baek, K.; Ok, Y.S.; Li, X.D. Chelant-enhanced washing of CCAcontaminated soil: Coupled with selective dissolution or soil stabilization. Sci. Total Environ. 2018, 612, 1463-1472. [CrossRef]

13. Gluhar, S.; Kaurin, A.; Lestan, D. Soil washing with biodegradable chelating agents and EDTA: Technological feasibility, remediation efficiency and environmental sustainability. Chemosphere 2020, 257, 127226. [CrossRef] [PubMed]

14. Sun, T.; Beiyuan, J.; Gielen, G.; Mao, X.; Song, Z.; Xu, S.; Ok, Y.S.; Rinklebe, J.; Liu, D.; Hou, D.; et al. Optimizing extraction procedures for better removal of potentially toxic elements during EDTA-assisted soil washing. J. Soils Sediments 2020, 20, 3417-3426. [CrossRef]

15. Makino, T.; Takano, H.; Kamiya, T.; Itou, T.; Sekiya, N.; Inahara, M.; Sakurai, Y. Restoration of cadmium-contaminated paddy soils by washing with ferric chloride: Cd extraction mechanism and bench-scale verification. Chemosphere 2008, 70, 1035-1043. [CrossRef]

16. Yu, X.A.; Zhou, T.; Zhao, J.; Dong, C.; Wu, L.; Luo, Y.; Christie, P. Remediation of a metal-contaminated soil by chemical washing and repeated phytoextraction: A field experiment. Int. J. Phytoremediat. 2021, 23, 577-584. [CrossRef] [PubMed]

17. Gao, J.; Zhao, J.; Dong, C.; Wu, L.; Hu, P. Remediation of metal-contaminated paddy soils by chemical washing with $\mathrm{FeCl}_{3}$ and citric acid. J. Soils Sediments 2018, 18, 1020-1028. [CrossRef]

18. Assawadithalerd, M.; Phasukarratchai, N. Optimization of cadmium and zinc removal from contaminated soil by surfactants using mixture design and central composite rotatable design. Water. Air Soil Pollut. 2020, 231, 329. [CrossRef] 
19. Peng, Y.; Zhang, S.; Zhong, Q.; Wang, G.; Feng, C.; Xu, X.; Pu, Y.; Guo, X. Removal of heavy metals from abandoned smelter contaminated soil with poly-phosphonic acid: Two-objective optimization based on washing efficiency and risk assessment. Chem. Eng. J. 2021, 421, 129882. [CrossRef]

20. Xia, Z.; Zhang, S.; Cao, Y.; Zhong, Q.; Wang, G.; Li, T.; Xu, X. Remediation of cadmium, lead and zinc in contaminated soil with CETSA and MA/AA. J. Hazard. Mater. 2019, 366, 177-183. [CrossRef]

21. Gusiatin, Z.M.; Radziemska, M. Saponin versus rhamnolipids for remediation of Cd contaminated soils. CLEAN-Soil Air Water 2018, 46, 1700071. [CrossRef]

22. Cao, Y.; Zhang, S.; Wang, G.; Huang, Q.; Li, T.; Xu, X. Removal of Pb, Zn, and Cd from contaminated soil by new washing agent from plant material. Environ. Sci. Pollut. Res. 2017, 24, 8525-8533. [CrossRef]

23. Chiang, P.N.; Tong, O.Y.; Chiou, C.S.; Lin, Y.A.; Wang, M.K.; Liu, C.C. Reclamation of zinc-contaminated soil using a dissolved organic carbon solution prepared using liquid fertilizer from food-waste composting. J. Hazard. Mater. 2016, 301, 100-105. [CrossRef]

24. Feng, C.; Zhang, S.; Li, L.; Wang, G.; Xu, X.; Li, T.; Zhong, Q. Feasibility of four wastes to remove heavy metals from contaminated soils. J. Environ. Manag. 2018, 212, 258-265. [CrossRef]

25. Gusiatin, Z.M.; Kulikowska, D.; Klik, B. New-generation washing agents in remediation of metal-polluted soils and methods for washing effluent treatment: A Review. Int. J. Environ. Res. Public Health 2020, 17, 6220. [CrossRef]

26. Liu, C.-C.; Chen, G.-B. Reclamation of cadmium-contaminated soil using dissolved organic matter solution originating from wine-processing waste sludge. J. Hazard. Mater. 2013, 244, 645-653. [CrossRef] [PubMed]

27. Klik, B.; Gusiatin, Z.M.; Kulikowska, D. A holistic approach to remediation of soil contaminated with $\mathrm{Cu}, \mathrm{Pb}$ and $\mathrm{Zn}$ with sewage sludge-derived washing agents and synthetic chelator. J. Clean. Prod. 2021, 311, 127664. [CrossRef]

28. Klik, B.; Gusiatin, Z.M.; Kulikowska, D. Kinetics of $\mathrm{Cu}, \mathrm{Pb}$ and $\mathrm{Zn}$ removal during soil flushing with washing agents derived from sewage sludge. Sci. Rep. 2021, 111, 10067. [CrossRef]

29. Klik, B.; Kulikowska, D.; Gusiatin, Z.M.; Pasieczna-Patkowska, S. Washing agents from sewage sludge: Efficiency of Cd removal from highly contaminated soils and effect on soil organic balance. J. Soils Sediments 2020, 20, 284-296. [CrossRef]

30. Kulikowska, D.; Klimiuk, E. Organic matter transformations and kinetics during sewage sludge composting in a two-stage system. Bioresour. Technol. 2011, 102, 10951-10958. [CrossRef] [PubMed]

31. Ostrowska, A.; Gawlinski, S.; Szczubiałka, Z. Analysis of Soils and Plants, 3rd ed.; Institute of Environmental Protection-National Research Institute: Warsaw, Poland, 1991.

32. Boratynski, K.; Wilk, K. Investigations on humus. Part IV. Fractionation of humus compounds with complexing solutions and diluted alkali solutions. Soil Sci. Annu. 1965, 15, 53-63.

33. Kulikowska, D.; Klik, B.K.; Gusiatin, Z.M.; Jabłoński, R. Sewage sludge can provide a washing agent for remediation of soil from a metallurgical area. Catena 2019, 173, 22-28. [CrossRef]

34. Pueyo, M.; Mateu, J.; Rigol, A.; Vidal, M.; López-Sánchez, J.F.; Rauret, G. Use of the modified BCR three-step sequential extraction procedure for the study of trace element dynamics in contaminated soils. Environ. Pollut. 2008, 152, 330-341. [CrossRef] [PubMed]

35. Casida, L.E.; Klein, D.A.; Santoro, T. Soil dehydrogenase activity. Soil Sci. 1964, 98, 371-376. [CrossRef]

36. Furtak, K.; Gajda, A.M. Activity of dehydrogenases as an indicator of soil environment quality. Polish J. Soil Sci. 2017, 50, 33-40. [CrossRef]

37. Juwarkar, A.A.; Nair, A.; Dubey, K.V.; Singh, S.K.; Devotta, S. Biosurfactant technology for remediation of cadmium and lead contaminated soils. Chemosphere 2007, 68, 1996-2002. [CrossRef] [PubMed]

38. Mgbeahuruike, L.U.; Barrett, J.; Potgieter, H.J.; Van Dyk, L.; Potgieter-Vermaak, S.S. A comparison of batch, column and heap leaching efficiencies for the recovery of heavy metals from artificially contaminated simulated soil. J. Environ. Prot. 2019, 10, 632-650. [CrossRef]

39. Ugwu, E.; Gupta, B.; Adeloye, A.J.; Martínez-Villegas, N. Column experiment for the removal of cadmium, copper, lead and zinc from artificially contaminated soil using EDTA, rhamnolipids, and soapnut. Eur. J. Environ. Earth Sci. 2021, 2, 1-7. [CrossRef]

40. Klik, B.K.; Gusiatin, Z.M.; Kulikowska, D. Suitability of environmental indices in assessment of soil remediation with conventional and next generation washing agents. Sci. Rep. 2020, 101, 20586. [CrossRef] [PubMed]

41. Gusiatin, Z.M.; Kaal, J.; Wasilewska, A.; Kumpiene, J.; Radziemska, M. Short-term soil flushing with tannic acid and its effect on metal mobilization and selected properties of calcareous soil. Int. J. Environ. Res. Public Health 2021, 18, 5698. [CrossRef] [PubMed]

42. Nejad, Z.D.; Rezania, S.; Jung, M.C.; Al-Ghamdi, A.A.; Mustafa, A.E.Z.M.; Elshikh, M.S. Effects of fine fractions of soil organic, semi-organic, and inorganic amendments on the mitigation of heavy metal(loid)s leaching and bioavailability in a post-mining area. Chemosphere 2021, 271, 129538. [CrossRef]

43. Leštan, D.; Luo, C.; Li, X. The use of chelating agents in the remediation of metal-contaminated soils: A review. Environ. Pollut. 2008, 153, 3-13. [CrossRef]

44. Wang, S.; Mulligan, C.N. An evaluation of surfactant foam technology in remediation of contaminated soil. Chemosphere 2004, 57, 1079-1089. [CrossRef] [PubMed]

45. Rothemel, R.K.; Petres, R.W.; St. Martin, E.; DeFlaun, M. Surfactant foam/bioaugmentation technology for in situ treatment of TCE-DNAPLs. Environ. Sci. Technol. 1998, 32, 1667-1675. [CrossRef] 
46. Wyszkowska, J.; Wyszkowski, M. Effect of cadmium and magnesium on enzymatic activity in soil. Polish J. Environ. Stud. 2003, $12,473-479$.

47. Vig, K.; Megharaj, M.; Sethunathan, N.; Naidu, R. Bioavailability and toxicity of cadmium to microorganisms and their activities in soil: A review. Adv. Environ. Res. 2003, 8, 121-135. [CrossRef]

48. Nannipieri, P. The potential use of soil enzymes as indicators of productivity, sustainability and pollution. In Soil Biota Management in Sustainable Farming Systems; Pankhurst, C.E., Double, B.M., Gupta, V.V.S.R., Grace, P.R., Eds.; CSIRO: Melbourne, Australia, 1994; pp. 238-244.

49. Yuan, B.C.; Yue, D.X. Soil microbial and enzymatic activities across a chronosequence of Chinese Pine plantation development on the Loess Plateau of China. Pedosphere 2012, 22, 1-12. [CrossRef]

50. Basak, B.; Biswas, D.R.; Pal, S. Soil biochemical properties and quality as affected by organic manures and mineral fertilizers in soil under maize-wheat rotation. Agrochimica 2013, 57, 49-66.

51. Moreno, J.L.; Sanchez-Marin, A.; Marin, M. Effect of cadmium on microbial activity and a ryegrass crop in two semiarid Soils. Environ. Manag. 2006, 37, 626-663. [CrossRef]

52. Lighthart, B.; Baham, J.; Volk, V.V. Microbial respiration and chemical speciation in metal-amended soils. J. Environ. Qual. 1983, 12, 543-548. [CrossRef]

53. Dar, G.H. Effects of cadmium and sewage-sludge on soil microbial biomass and enzyme activities. Bioresour. Technol. 1996, 56, 141-145. [CrossRef]

54. Kuo, S.; Baker, A.S. Sorption of copper, zinc, and cadmium by some acid soils. Soil Sci. Soc. Am. J. 1980, 44, 969-974. [CrossRef]

55. Doelman, P.; Haanstra, L. Short-term and long-term effects of cadmium, chromium, copper, nickel, lead and zinc on soil microbial respiration in relation to abiotic soil factors. Plant Soil 1984, 79, 317-327. [CrossRef] 